\title{
Physiological responses of Triplaris gardneriana Wedd. seedlings (Polygonaceae) under intermittent drought
}

Respostas fisiológicas de mudas de Triplaris gardneriana Wedd. (Polygonaceae) sob seca intermitente

\author{
E. C. da Silva ${ }^{1 *}$; J. R. V. Aragão²; I. B. Bipo ${ }^{1}$; I. C. Menezes ${ }^{1}$; H. H. C. do \\ Nascimento ${ }^{3}$ \\ ${ }^{1}$ Laboratório de Fisiologia e Ecofisiologia Vegetal, Departamento de Biologia, Universidade Federal de Sergipe, \\ 49100-000, São Cristóvão-SE, Brasil \\ ${ }^{2}$ Departamento de Biologia Vegetal, Laboratório de Ecologia Vegetal, Instituto de Biologia, Universidade Estadual \\ de Campinas, 13083-970, Campinas-SP, Brasil \\ ${ }^{3}$ Laboratório de Tecnologia da Produção, Campus de Engenharias e Ciências Agrárias, Universidade Federal de \\ Alagoas, 57100-000, Rio Largo-AL, Brasil \\ *elizaciriaco@gmail.com \\ (Recebido em 16 de março de 2021; aceito em 23 de dezembro de 2021)
}

\begin{abstract}
Triplaris gardneriana Wedd is a deciduous riparian tree occurring in areas with different climatic conditions in Brazil, from the rainforest to the tropical dry forest. An increase in global temperature and drought events can change the growth pattern and establishment of the species. To evaluate the effects of intermittent drought on the growth of $T$. gardneriana seedlings, an experiment was performed using seedlings with one month old subjected to three water treatments (daily irrigation as control, and intermittent drought through cycles of water suppression of seven (S7) and 14 days-intervals (S14) between watering. Growth, biomass production and partitioning, relative water content (RWC), the accumulation of organic solutes, protoplasmic integrity and phenotypic plasticity index (PPI) were evaluated for a better understanding about its drought tolerance level. Intermittent drought severely affected plants growth in S14 plants, showing lower plant height, number of leaves, leaf area, and dry biomass. RWC was reduced, while carbohydrates and proline contents increased in response to drought stress. Protoplasmic damage increased electrolyte leakage in plants subjected to severe stress. However, T. garderiana demonstrated moderate tolerance to water deficit. The plastic changes observed were more physiological than morphological. Therefore, $T$. gardneriana seems to be a moderately tolerant species to intermittent drought.

Keywords: biomass partitioning, proline, water deficit.
\end{abstract}

Triplaris gardneriana Wedd é uma espécie arbórea que ocorre em áreas com diferentes condições climáticas no Brasil, desde florestas tropicais úmidas a florestas tropicais secas. Um aumento crescente na temperatura global e nos eventos de seca pode modificar o padrão de crescimento e estabelecimento da espécie. Para avaliar os efeitos da seca intermitente sobre o crescimento de mudas de T. gardneriana, foi desenvolvido um experimento utilizando mudas de um mês de idade submetidas a três tratamentos hídricos [rega diária como controle e seca intermitente por ciclos de suspensão de rega em intervalos de sete (S7) e quatorze dias (S14) entre regas]. O crescimento, produção e partição de biomassa, conteúdo relativo de água (CRA), acúmulo de solutos orgânicos, integridade protoplasmática e índice de plasticidade fenotípica (IPF) foram avaliados para uma melhor compreensão no grau de tolerância à seca. A seca intermitente afetou severamente o crescimento das plantas S14, apresentando menor altura, número de folhas, área foliar e biomassa seca. O CRA foi reduzido, enquanto que a concentração de carboidratos e prolina aumentaram em resposta ao estresse hídrico. Os danos protoplasmáticos aumentaram a extrusão de eletrólitos nas plantas submetidas ao estresse severo. Entretanto, T. garderiana demonstrou tolerância moderada ao déficit hídrico. As mudanças plásticas observadas foram mais fisiológicas do que morfológicas. Portanto, a espécie T. gardneriana demonstrou ser moderadamente tolerante à seca intermitente.

Palavras-chave: déficit hídrico, partição de biomassa, prolina.

\section{INTRODUCTION}

Growth and establishment of seedlings in the environment depend on favorable climate and soil conditions as well as the genetic capacity of species to cope with seasonal changes. Thus, 
species with greater adaptation to a particular environment are more successful in terms of establishment [1,2].

The seasonally dry tropical forest in Northeastern Brazil, denominated Caatinga, is characterized by low annual rainfall, with irregular rain distribution concentrated in two to three months, followed by a long period of drought, high temperatures and low relative air humidity [3, 4]. These conditions generate water deficit in the soil, which is a stress factor for plants that affects growth and development, especially for seedlings in the field $[5,6]$, which is recognized as the most critical phase to plants establishment. Dehydration in this phase can result in death [7].

Because of their small roots, seedlings has limited capacity to the soil exploration for water and nutrients $[7,8]$. Surviving such conditions requires adaptive mechanisms that enable better management of the available water through metabolic adjustments, modification of physiological aspects, reversible cellular adjustments or modification of morphology and anatomy [4, 9]. Growth rates, especially in length, are generally inhibited and some species exhibit changes in the growth pattern as the main adaptive characteristic, such as an increased root system at the expense of shoot growth $[4,9]$. These changes reduce the loss of water through leaf transpiration and allow the exploration of deeper layers of soil for moisture $[7,10,11]$.

Despite changes in structure and architecture, drought adversely affects metabolic processes, such as the metabolism of protein and carbohydrates [12], and some of these organic compounds participate as osmoregulators or osmoprotectants. An osmotic adjustment can be achieved by the accumulation of organic compounds of low molecular weight, such as carbohydrates, organic acids, soluble proteins, proline and glycine betaine $[6,13,14]$, which ensure the influx of water and therefore cell turgor. Some of these substances play also an important role in protecting biomembranes and enzymes, besides their importance to the scavenging of oxygen radicals [1417], and are degraded soon after the recovery from stress [12, 13].

Triplaris gardneriana Wedd (Polygonaceae), locally known as pajeú, is a deciduous riparian tree [18] with simple, broad, leathery leaves that occurs in different region of Brazil. This species is reported as pioneer, heliophyte and fast growing, showing good features for its use in reforestation and recovery of degraded areas programs [19]. It has been recorded in the Amazon rainforest (Northern region) [20], in the Pantanal wetland in the state of Mato Grosso (central Western region) [21] and the Caatinga in the São Francisco Valley (Northeastern region) [20, 22]. According to Fagundes et al. (2018) [19] seedlings of T. gardneriana displayed a great capacity to survive in a degraded riparian area in the Cerrado (savanna) along the first year of reforestation, demonstrating its great plasticity for inhabit in a heterogeneous environment, because over the years the seedlings faced dry season, even in riparian areas.

Due to the lack of studies on the physiological responses of $T$. gardneriana seedlings under drought conditions, the present study constitutes a significant contribution to advancing the knowledge on the physiology and stress tolerance of this economically and ecologically relevant tree. Hence, we tested the hypothesis that (i) seedlings would adjust to drought conditions through changes in growth pattern and (ii) the accumulation of osmoregulators compounds in the leaves and roots could maintain these tissues hydrated with appropriate metabolic rates. Thus, the present study aimed to evaluate the physiological responses of Triplaris gardneriana Wedd. subjected to intermittent drought to verify the level of drought tolerance in the seedlings through the analysis of initial growth parameters, relative water content in leaves, the accumulation of organic solutes and protoplasmic integrity, and evaluate whether such possible changes could confer morpho-physiological plasticity in seedlings.

\section{MATERIAL E METHODS}

\subsection{Plant material and experimental conditions}

The experiment was performed in a greenhouse at the Biology Department of Universidade Federal de Sergipe (UFS), Brazil (10 55'29.32" S, $37^{\circ} 6^{\prime} 1.98^{\prime}$ ' W). Air temperature and relative humidity were recorded every 30 minutes with a thermo-hygro-station (KlimaLogg Pro). Mean temperature was $28,8{ }^{\circ} \mathrm{C}$ (range: $21-36,9^{\circ} \mathrm{C}$ ), and mean relative humidity was $72,5 \%$ (range: 
42-80\%). Seeds of T. gardneriana were obtained from Núcleo de Ecologia e Monitoramento Ambiental (NEMA), Petrolina, PE, Brazil, and they were collected in a semiarid area, at the Municipality of Barro, Ceará State, Brazil (7 4' 57.9"S; 38 44' 48.2"W).

The seeds were germinated in trays containing washed sand in greenhouse conditions. After emergence, thirty seedlings were selected based on their uniformity in size and appearance and transplanted to polyethylene vases containing two liters of topsoil. They were watered and kept at near field capacity (soil moisture: $~ 19 \%$ ) during 15 days for acclimation. After this period, seedlings were randomly separated in three groups. Field capacity was determined by the gravimetric method $[23,24]$ and measured in this condition with a portable Farm Meter (Model HFM 2010, Falker).

A completely randomized design was used with three water treatments and 10 replicates per treatment: control with daily watering and intermittent drought through cycles of water suppression of seven (S7) and 14 days-intervals (S14) between watering. Plant height, number of leaves, and stem diameter were evaluated as repeated measures in time (total of 11 samplings). Relative water content, organic solutes and protoplasmic integrity were evaluated at the end of the experimental period (73 days after the beginning of treatments).

\subsection{Growth variables}

Growth variables were evaluated weekly for a period of 73 days. Plant height and stem diameter were measured using a ruler or digital calipers (Digimess, model DDIN 862), measuring always starting at the same pre-marked point - approximately $1.0 \mathrm{~cm}$ above the soil. All fully expanded leaves were also counted. At the end of the experimental period, leaf area (LA) was determined using the leaf outline method [24], as described by Freitas and Silva (2018) [25].

Different plant organs were stored in paper bags and placed in a circulating forced air oven at $70{ }^{\circ} \mathrm{C}$ until reaching a constant weight. This material was weighed to determine the dry mass (DMW). With these data, the shoot-to-root ratio (S/R), biomass partitioning to the various organs, leaf area ratio (LAR) and specific leaf area (SLA) were calculated according to Benincasa (2003) [24].

\subsection{Relative water content (RWC) and protoplasmic integrity}

The relative water content (RWC) was determined by removing six discs of the leaf blade using a metal punch with a diameter of $1.0 \mathrm{~cm}$. Discs were weighed to obtain fresh mass weight (FMW) and placed in Petri dishes with distilled water and covered with black plastic to protect from the light for 24 hours under laboratory conditions (around $23{ }^{\circ} \mathrm{C}$ ). After this period, this material was weighed again to determine the turgid matter weight (TMW) and it was placed in the oven in paper bags for 72 hours to obtain the dry mass weight (DMW). RWC was calculated according to Weatherley, (1950)[26] and expressed as a percentage value: $\mathrm{RWC}=($ FMW-DMW $)$ / (TMW-DMW) x 100.

The percentage of protoplasmic damage was assessed by the release electrolytes from leaf discs. Ten discs measuring $1.0 \mathrm{~cm}$ in diameter were taken from the leaf blade using 10 plants per treatment, immersed in $10 \mathrm{ml}$ of distilled water and left at room temperature (about $23{ }^{\circ} \mathrm{C}$ ) for $24 \mathrm{~h}$. After this period, free conductivity (FC) was measured with a portable conductivity meter (PHTECH CD203) and tubes with the leaf discs were placed in a water bath at $100{ }^{\circ} \mathrm{C}$ for one hour. After cooling, electrical conductivity was measured again, which was denominated total conductivity (TC). From these data, the absolute integrity percentage (AIP $=1-\mathrm{FC} / \mathrm{TC}$ ), relative integrity percentage $(\mathrm{RIP}=$ AIP stressed plants / AIP irrigated plants $)$ and percentage of protoplasmic damage $(\mathrm{PD}=100-\mathrm{RIP})$ were calculated [27]. 


\subsection{Osmotically active organic solutes}

Leaf and root samples were collected and frozen at $-18{ }^{\circ} \mathrm{C}$ in a freezer until the biochemical analyzes at the end of the trial. Extracts were prepared by grinding approximately $500 \mathrm{mg}$ of material with $5 \mathrm{ml}$ of $0.1 \mathrm{M}$ monobasic phosphate buffer containing $0.1 \mathrm{mM}$ EDTA, pH 7.0 [17]. The mash was centrifuged at $8,000 \mathrm{x} g$ for 10 minutes. The supernatant was removed and placed in Eppendorf tubes with a 2-ml capacity and frozen until analysis.

After the preparation of the extracts, free proline, total soluble protein and soluble carbohydrates in the leaves and roots were determined. Free proline content was measured and was determined colorimetrically at $520 \mathrm{~nm}$ in a $1.0-\mathrm{ml}$ aliquot of crude extract, using ninhydrin as the specific reagent and pure proline as the standard [28]. Soluble proteins were determined colorimetrically using the dye-binding method according to Bradford (1976) [29], with pure bovine serum albumin as the standard. A $0.2-\mathrm{ml}$ aliquot of crude extract was used, to which $2.0 \mathrm{ml}$ of the Bradford specific reagent were added. Total soluble carbohydrates were determined [30] in an aliquot of $500 \mu \mathrm{L}$ of crude extract, $500 \mu \mathrm{L}$ of $5 \%$ phenol and $2.5 \mathrm{ml}$ of concentrated sulfuric acid. Readings were then carried out in a spectrophotometer at $490 \mathrm{~nm}$.

\subsection{Soil moisture}

Reduction in soil moisture was measured using a portable Farm Meter (Model HFM 2010, Falker) at weekly intervals for the control and S7 plants, and every 14-day intervals for the S14 plants before re-irrigation. Approximately one hour after re-irrigation, the soil moisture of all plants was checked again for the verification of moisture near field capacity $(\sim 19 \%)$.

\subsection{Phenotypic plasticity index (PPI)}

The phenotypic plasticity index ( 0 to 1 ) of each morphological and physiological variable was calculated as the difference between the highest and the lowest mean value among the treatments, divided by the highest mean value [31]. A higher PPI indicates greater plasticity of the variable analyzed $[2,32]$. The between-treatment variation index is a reliable estimator of phenotypic plasticity [31].

\subsection{Statistical analysis}

Statistical analysis was performed using the Assistat 7.7 Beta and SigmaPlot 11.0 programs. Plant height, number of leaves and stem diameter were analyzed using repeated-measures ANOVA and the means compared using Tukey's multiple range test $(\mathrm{P}<0.05)$. Principal component analysis (PCA) was also conducted to evaluate the formation of groups between the treatments under water stress, followed by the use of general linear models (GLMs) to determine possible cause-effect relationship between the PCA-weighted morpho-physiological components. PCA uses data weighting to search for patterns in groups within a correlation matrix or variancecovariance [33]. Significant relationships determined by GLMs were subjected to Pearson's correlation analysis to identify the influence of water stress on morpho-physiological characters in comparison to the control plants. Past $2.17 \mathrm{c}$ software was used for these analyses.

\section{RESULTS}

The cycles of fourteen days of water suppression $(\mathrm{S} 14)$ significantly $(\mathrm{P}<0.05)$ affected the growth of $T$ gardneriana seedlings. The lowest mean values were found in plant height, the number of leaves, stem diameter, leaf area and the dry matter production of different organs in the stressed plants (Figures 1, 2 and 3).

Although no stunting in growth occurred in terms of height, plants cultivated with a 14-day interval between watering (S14) exhibited a significantly lower value in growth beginning from 
the $29^{\text {th }}$ day after the differentiation of the water treatments (Figure 1A). This difference became more pronounced with the prolongation of the stress period, showing a $27.8 \%$ reduction in comparison to control plants. In contrast, plants grown with a seven-day interval between watering (S7) exhibited similar growth to that found in the control plants (Figure 1A).

Variations were observed in the number of leaves throughout the experimental period in all treatments, with a low rate of budding leaves and sporadic falls, independently of the water treatment, although more pronounced in plants cultivated under intermittent drought conditions (Figure 1B). This difference was more pronounced at the end of the experimental period, with a greater reduction in the plants subjected to more severe stress (S14).

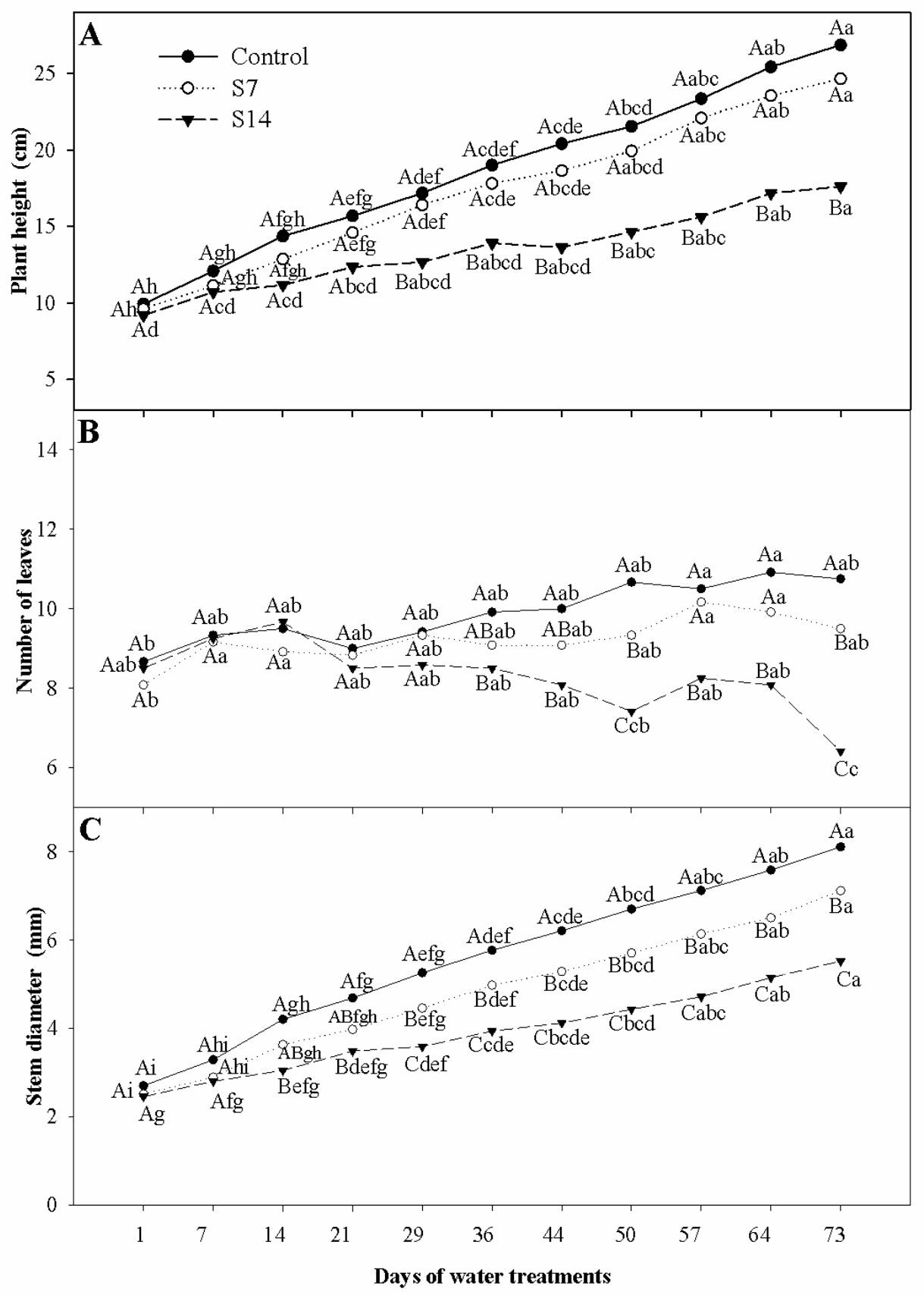

Figure 1: Plant height (A), number of leaves $(B)$ and stem diameter $(C)$ of Triplaris gardneriana Wedd. seedlings over time and subjected to water deficit by withholding water cycles. Control (daily watering),

$S 7$ and S14 (seven and fourteen-days intervals between watering, respectively). Means followed by different letters (upper case among treatments and lower case among days) differ by Tukey's multiple range test $(P<0.05)$ 
Water deficit also affected stem diameter, with a reduction beginning on the $14^{\text {th }}$ day in the S14 plants. In S7 plants, this reduction was found beginning on the $14^{\text {th }}$ day of treatment and extended throughout the experimental period. At $73^{\circ}$ day, the reduction was $13.6 \%$ for S7 plants and $30 \%$ for S14 plants (Figure 1C).

Leaf area of stressed plants (S14) was $46.5 \%$ smaller than control plants (Figure 2A), whereas plants subjected to seven-day intervals of withholding water (S7) did not differ significantly from the control plants $(\mathrm{P}<0.05)$. Regarding the leaf area ratio (LAR), a $25 \%$ increase was found in S14 plants compared to the control (Figure 2B), but the specific leaf area (SLA) was not significantly reduced (Figure 2C).

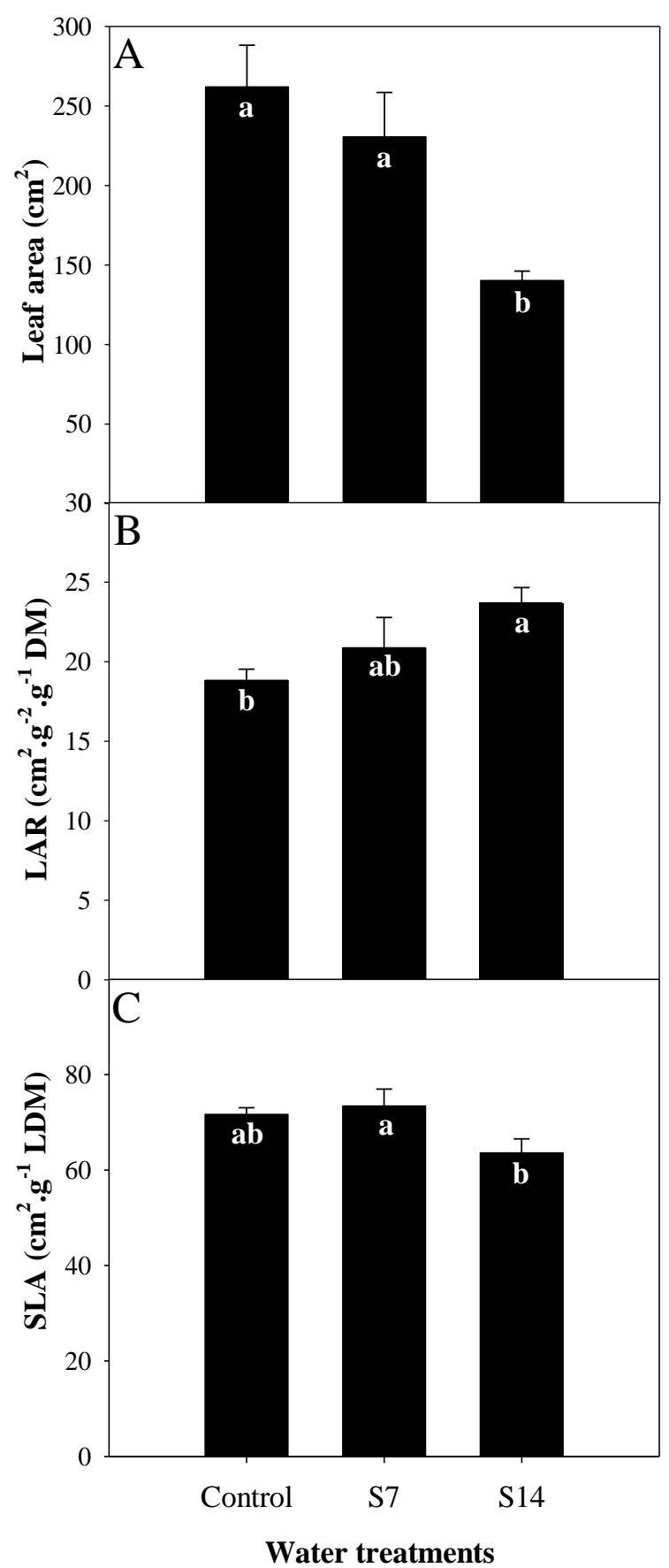

Figure 2: Leaf area $(A)$, leaf area ratio $(L A R)(B)$ and specific leaf area $(S L A)(C)$ of Triplaris gardneriana Wedd. seedlings subjected to water deficit by withholding water cycles. Control (daily watering), S7 and S14 (seven and fourteen days-intervals between watering, respectively). Means followed by different letters differ by Tukey's multiple range test $(P<0.05)$. 
Dry mass of the leaves $(\mathrm{LDM})$ was lower $(P<0.05)$ only in the plants cultivated with a 14-day interval between watering (Figure 3A), whereas stem (SDM), root dry mass (RDM) and total dry mass (TDM) were reduced in both the S7 and S14 plants (Figures 3B, C and D). These reductions were approximately $38 \%$ for LDM, $60 \%$ for SDM, $66 \%$ for RDM and $57 \%$ for TDM in S14 plants. Regarding the S7 plants, the reduction was approximately 23\% for SDM, $30 \%$ for RDM and $27 \%$ for TDM.

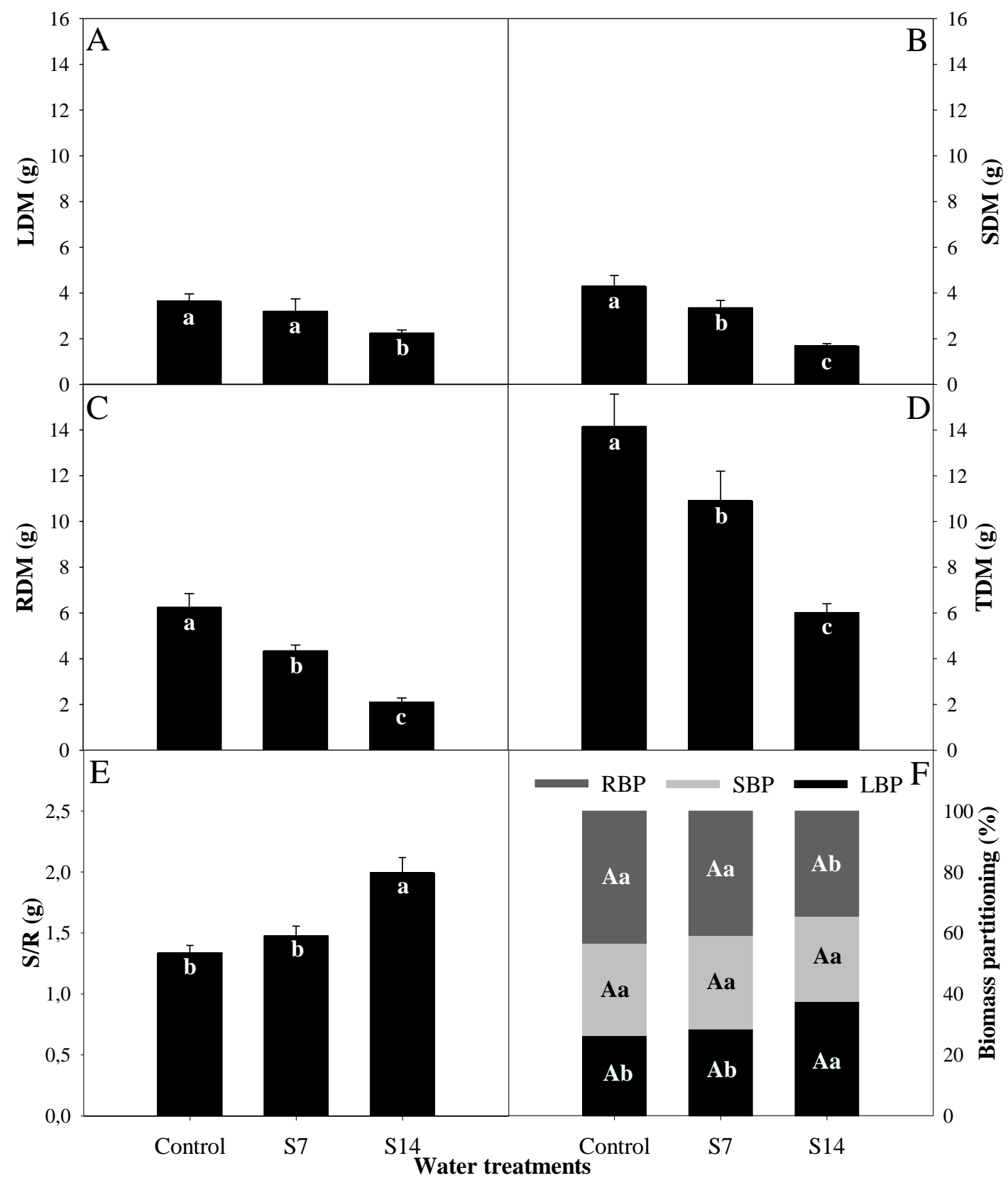

Figure 3: Leaf dry mass (LDM), stem dry mass (SDM), roots dry mass (RDM), total dry mass (TDM) (A, $B, C$ and $D)$, Shoot to root ratio $(S / R)(E)$ and biomass partitioning $(R B P$ - roots biomass partitioning; SBP- stem biomass partitioning; LBP- leaves biomass partitioning) ( $F$ ) of Triplaris gardneriana Wedd. seedlings subjected to water deficit by withholding water cycles. Control (daily watering), S7 and S14 (seven and fourteen days-intervals between watering, respectively). Means followed by different letters (for biomass partitioning, uppercase among plant parts and lower case among treatments) differ by Tukey's multiple range test $(P<0.05)$. 
An increase was found in the shoot-to-root ratio (S/R) in the S14 plants (49\%) compared to the control plants (Figure 3E). This result demonstrates a change in the plant growth pattern among stressed plants, which began to invest more in the shoots biomass (leaves and stem) than in the root system. This was confirmed by the dry biomass partitioning to the different organs (Figure 3F), as S14 plants invested about $40 \%$ of the assimilated partitioning to the dry matter production of the leaves, which is higher than that found in the control and S7 plants, whereas the percentage destined to the production of the roots was lower. Between the plant parts, no statistical differences were found.

Relative water content (RWC) in the leaves of S7 seedlings did not differ significantly from control plants, but seedlings in S14 treatment had very low RWC $(\mathrm{P}<0.05)$ at the end of the experimental period (72 days under cycles of withholding water), with average values of only $37 \%$, representing a reduction of $54 \%$ in comparison to the plants daily watered (Table 1).

Analyzing protoplasmic tolerance to drought in the T. gardneriana seedlings, greater extrusion of electrolytes was found in the more stressed plants (S14) than in the other treatments. Thus, the absolute integrity percentage (AIP) was only $49 \%$ in these plants, while values were above $76 \%$ in the other treatments (Table 1).

Table 1. Relative Water Content $(R W C)$, absolute integrity percentage $(A I P)$, relative integrity percentage $(R I P)$ and percentage of damage $(P D)$ in leaves of Triplaris gardneriana Wedd. seedlings submitted to different withholding water cycles. Control (daily watering), S7 and S14 (seven and fourteen daysintervals between watering, respectively).

\begin{tabular}{lcccc}
\hline Trataments & RWC $(\%)$ & AIP $(\%)$ & RIP $(\%)$ & PD $(\%)$ \\
\hline Control & $81.8 \mathrm{a}$ & $76.8 \mathrm{a}$ & - & - \\
S 7 & $80.2 \mathrm{a}$ & $79.7 \mathrm{a}$ & $103.8 \mathrm{a}$ & $-3.8 \mathrm{a}$ \\
S 14 & $37.3 \mathrm{~b}$ & $49.1 \mathrm{~b}$ & $63.9 \mathrm{~b}$ & $36.1 \mathrm{~b}$ \\
\hline \multicolumn{2}{l}{ Means followed by different letters differ by Tukey's multiple range test $(P<0.05)}$.
\end{tabular}

Means followed by different letters differ by Tukey's multiple range test $(P<0.05)$.

Concerning the protoplasmic relative integrity percentage (RIP) and the percentage of damage (PD), no difference was found between S7 and control plants. The negative value of PD indicates greater integrity in S7 plants than the control treatment. It does demonstrate that a seven-day interval between watering did not negatively affect the integrity of the membranes. In contrast, the drought cycles negatively affected the cell membrane in S14 treatment when tissue hydration became very low (RWC less than $40 \%$ ) (Table 1 ).

Triplaris gardneriana seedlings accumulated higher concentrations of carbohydrates in the leaves than in the roots, regardless of the water treatment (Figures 4A-B), whereas the concentrations of soluble proteins in the roots were much higher than those found in the leaves (Figures 4C-D).

Comparing the analyses of organic compounds, total soluble carbohydrates and free proline contents in the leaves were significantly $(\mathrm{P}<0.05)$ higher in the $\mathrm{S} 14$ plants than in the control and S7 plants (Figures 4A-B-E-F). Specifically, for proline, the increase was on an expressive magnitude (> 30 times). In contrast, no significant accumulation of solutes was found in the roots of S14 seedlings, but it was found in the S7 seedlings, which was approximately 2.5 -times greater than in the control and S14 plants (Figures 4E-F). 


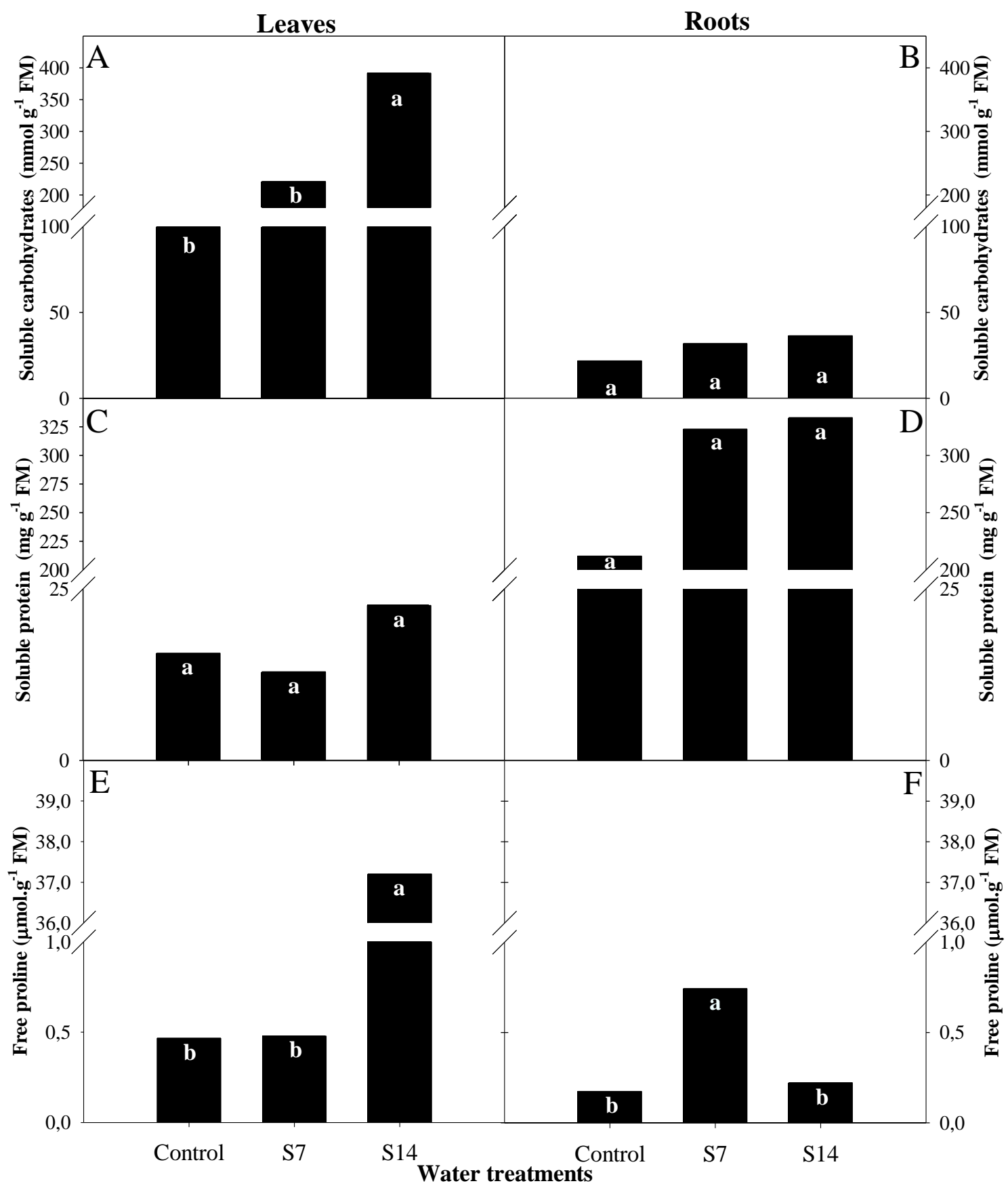

Figure 4. Total soluble carbohydrates, soluble proteins and free proline in leaves (A, $C$ and $E$ ) and roots $(B, D$ and $F)$ of Triplaris gardneriana Wedd. seedlings subjected to water deficit by withholding water cycles. Control (daily watering), S7 and S14 (seven and fourteen-day intervals between watering, respectively). Means followed by different letters differ by Tukey's multiple range test $(P<0.05)$.

Analyzing the phenotypic plasticity index (PPI) for the morphological variables, $T$. gardneriana demonstrated an index above 0.6 for the stem and roots dry matter and a lowest index for all other morphological variables. For physiological variables, however, proline had the highest index, to leaves and roots (0.9 and 0.8, respectively) (Figure 5). 


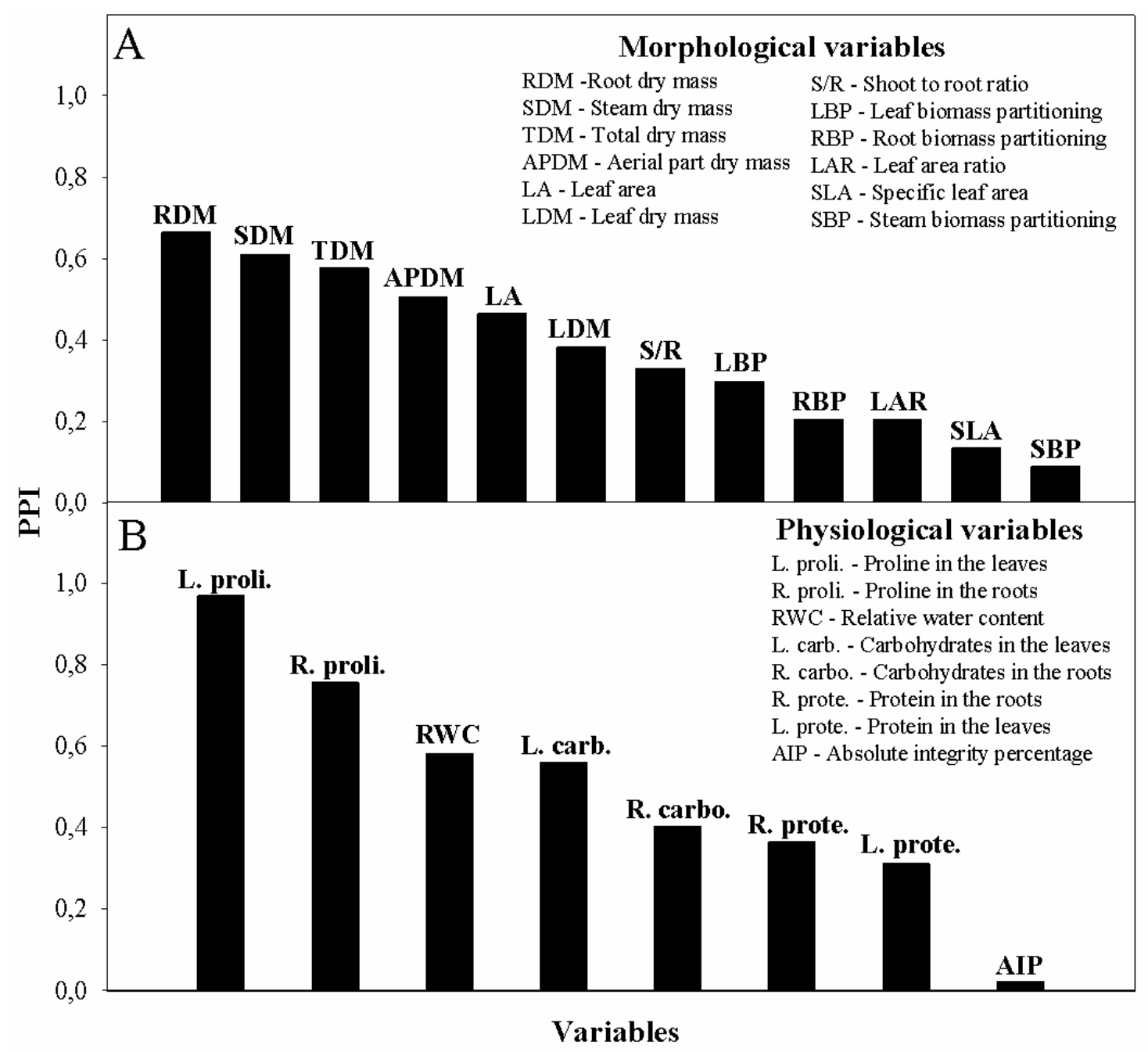

Figure 5: Phenotypic plasticity index (PPI) to morphological (A), and physiological $(B)$ variables of Triplaris gardneriana Wedd. Seedlings subjected to water deficit by cycles of withholding water.

PCA results showed the complete differentiation of the S14 plants concerning the accumulation of organic solutes, and the biomass partitioning of the leaves due to the imposed water stress. The S7 plants exhibited shared characteristics with the control plants, but with divergence in the variables RWC, PH, SLA, SBP and RBP (Figure 6). 


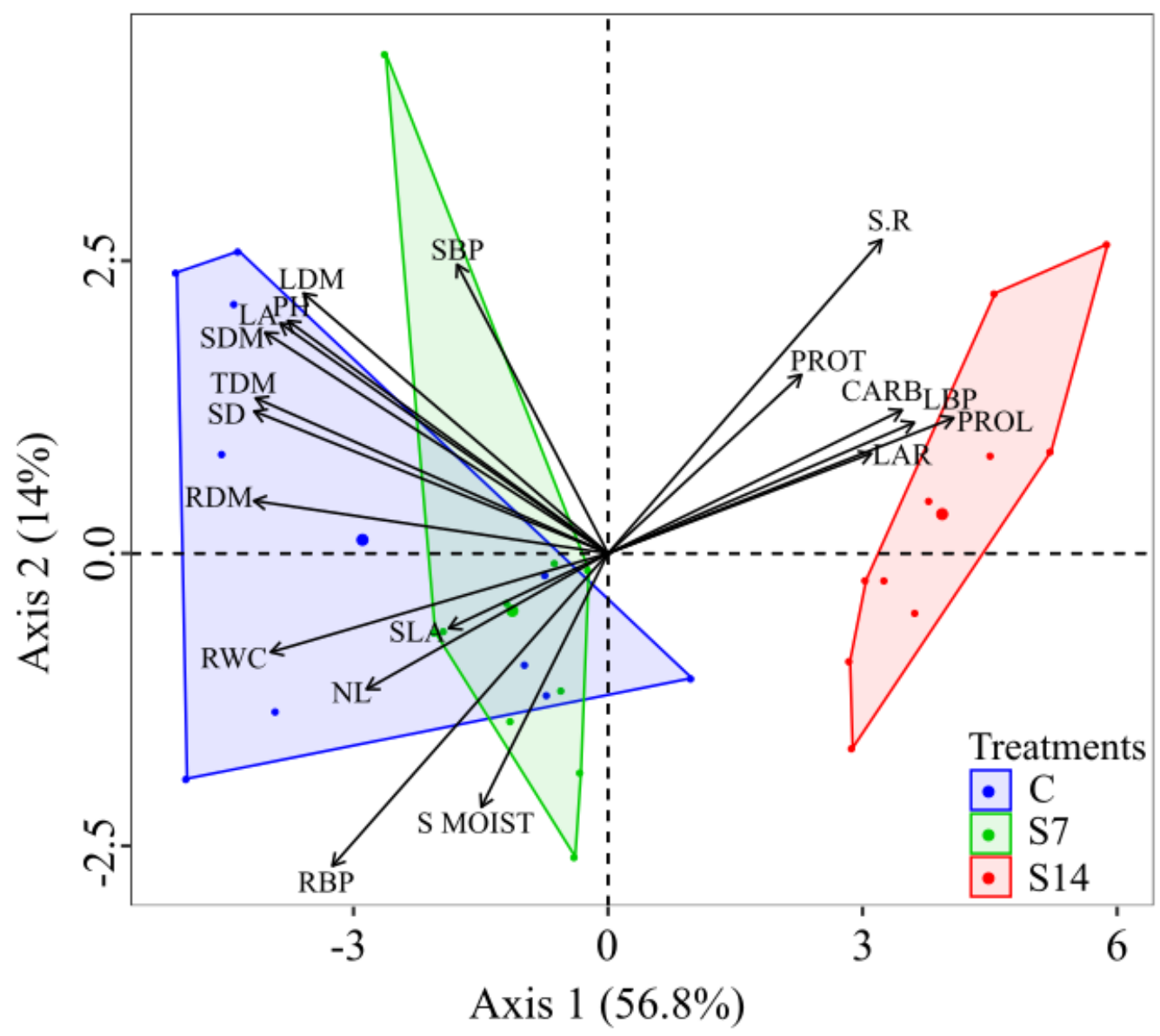

Figure 6: Principal components analysis (PCA) of morpho-physiological variables of Triplaris gardneriana Wedd. seedlings subjected to water deficit by cycles of withholding water. $\square$ : Control (daily watering); O: S7 (seven-days interval of watering); $\Delta: S 14$ (fourteen-days interval of watering). RWC: relative water content; $P H$ : plant height; $N L$ : number of leaves; SD: stem diameter; LA: leaf area; LAR: leaf area ratio; SLA: specific leaf area; LDM: leaf dry mass; SDM: stem dry mass; RDM: root dry mass; TDM: total dry mass; CARB: carbohydrates; PROT: protein; PROL: proline; S_MOIST: soil moisture; LBP: leaves biomass partitioning; SBP: stem biomass partitioning; RBP: root biomass partitioning; S/R: shoot-to-root.

The GLMs showed the strong relationship between the morphological and physiological data determined using PCA (Table 2), especially RWC, which was significantly related to all variables, except soil moisture. The reduction in RWC influenced a decrease in height and stem diameter, respectively, by up to $68 \%$ and $70 \%$. Indeed, soil moisture had the lowest number of significant relationships of all variables evaluated, which indicates the lower influence of soil humidity with the other traits for T. gardneriana. Pearson's correlations revealed the weight of the relationships pre-defined by GLMs, with values either directly or inversely influenced by morphophysiological features, with direct relationships of up to 0.97 (SD x TDM) and inverse relationships of -0.91 (RWC x PROL; Table 2). 
Table 2: Analysis of generalized linear models (GLM) (values above*) and Pearson correlations (values below *) of the morphophysiological attributes of Triplaris gardneriana seedlings subjected to water deficit by cycles of withholding water. Control (watered daily), S7 (watered every 7 days) and S14

(watered every 14 days). Bold values: significant at $P<0.05$.

\begin{tabular}{|c|c|c|c|c|c|c|c|c|c|c|c|c|c|c|c|c|c|c|c|}
\hline & RWC & $\mathrm{PH}$ & NL & SD & LA & LAR & SLA & DM & SDM & RDM & TDM & CARB & PROT & PROL & S_MOIST & LBP & SBP & RBP & $\mathrm{S} / \mathrm{R}$ \\
\hline $\mathrm{NC}$ & $*$ & 0.001 & 0.001 & 0.001 & 0.001 & 0.001 & 0.006 & 0.001 & 0.001 & 0.001 & 0.001 & 0.001 & 0.001 & 0.001 & 0.145 & 0.001 & 0.009 & 0.001 & 0.001 \\
\hline $\mathrm{PH}$ & 0.680 & $*$ & 001 & 0.001 & 0.001 & 0.029 & 0.006 & 0.001 & 0.001 & 0.001 & 0.001 & 0.005 & 0.050 & 0.001 & 980 & .001 & 0.001 & 0.060 & 0.051 \\
\hline NL & 0.680 & 0.532 & $*$ & 0.007 & 0.015 & 0.196 & 0.001 & 0.130 & 0.022 & 0.009 & 0.018 & 0.002 & 0.001 & 0.002 & 530 & 001 & 0.140 & 0.001 & 0.001 \\
\hline SD & 0.702 & 0.839 & 0.454 & $*$ & 0.001 & 0.001 & 0.196 & 0.001 & 0.001 & 0.001 & 0.001 & 0.001 & 0.060 & 0.001 & 340 & 001 & 0.024 & 0.001 & 0.001 \\
\hline LA & 0.623 & 0.905 & 0.418 & 0.908 & $*$ & 0.028 & 0.033 & 0.001 & 0.001 & 0.001 & 0.001 & 0.002 & 0.156 & 0.001 & .540 & 001 & 0.008 & 0.023 & 0.022 \\
\hline LAR & -0.582 & -0.380 & -0.237 & -0.649 & -0.384 & $*$ & 0.208 & 0.002 & 0.001 & 0.001 & 0.001 & 0.001 & 0.110 & 0.001 & .031 & .001 & 0.495 & 0.001 & 0.001 \\
\hline SLA & 0.463 & 0.458 & 0.555 & 0.237 & 0.374 & 0.231 & $*$ & 0.646 & 0.124 & 0.179 & 0.206 & 0.416 & 0.070 & 116 & 360 & 001 & 0.046 & 0.025 & 0.016 \\
\hline LDM & 0.528 & 0.821 & 0.274 & 0.905 & 0.955 & -0.496 & 0.086 & 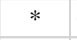 & 0.001 & 0.001 & 0.001 & 0.002 & 0.320 & 0.002 & 660 & 002 & 0.050 & 0.072 & 0.079 \\
\hline DM & 660 & 0.908 & 0.396 & 0.940 & 0.951 & -0. & 0.279 & 0.931 & $*$ & 0.001 & 0.001 & 0.001 & 0.178 & 1 & 393 & 01 & 0.001 & 0.014 & 0.015 \\
\hline RDM & 668 & 0.750 & 0.443 & 0.946 & 0.859 & & 0.246 & 0.854 & 0.901 & $*$ & .001 & 0.001 & 0.088 & 0.001 & 50 & .001 & 0.228 & 0.001 & 0.001 \\
\hline TDM & 0.660 & 0.845 & 0.407 & 0.969 & 0.941 & & 0.232 & 0.942 & 0.973 & 0.971 & $*$ & 0.001 & 0.360 & 0.001 & 191 & 0.001 & 0.037 & 0.001 & 0.001 \\
\hline CARB & $-0.833-$ & & -0.51 & -0.635 & & & -0.152 & 198 & -0.548 & -0.607 & -0.586 & $*$ & 0.002 & 0.001 & 0.105 & 0.001 & 0.375 & 0.001 & 0.001 \\
\hline PROT & $-0.633-$ & & & & -0.259 & 0.287 & -0.323 & -0.185 & -0.247 & -0.306 & -0.271 & 0.504 & $*$ & 0.001 & 0.920 & 0.006 & 0.536 & 0.015 & 0.016 \\
\hline PROL & $-0.910-$ & -0 . & -0.5 & & & 0.612 & -0.284 & -0.499 & -0.581 & -0.593 & -0.590 & 0.859 & 0.623 & $*$ & 0.038 & 0.001 & 0.089 & 0.001 & 0.001 \\
\hline S_MOIST & 0.265 & 0.005 & 0.117 & 0.177 & 0.115 & -0.377 & 0.170 & 0.082 & 0.159 & 0.347 & 0.240 & -0.293 & -0.019 & -0.364 & $*$ & 0.012 & 0.566 & 0.001 & 0.003 \\
\hline LBP & -0.841 & -0.679 & -0.649 & -0.737 & -0.622 & 0.663 & -0.567 & -0.498 & -0.706 & -0.794 & -0.730 & 0.654 & 0.460 & 0.704 & -0.430 & $*$ & 0.036 & 0.001 & 0.001 \\
\hline SBP & 0.445 & 0.660 & 0.269 & 0.391 & 0.446 & -0.128 & 0.353 & 0.347 & 0.548 & 0.222 & 0.367 & -0.165 & -0.116 & -0.305 & -0.108 & -0.369 & * & 0.283 & 0.352 \\
\hline RBP & 0.626 & 0.329 & 0.526 & 0.547 & 0.394 & -0.624 & 0.391 & 0.322 & 0.422 & 0.707 & 0.554 & -0.592 & -0.417 & -0.563 & 0.517 & -0.838 & -0.199 & $*$ & 0.001 \\
\hline S/R & -0.642 & -0.346 & -0.540 & -0.516 & -0.396 & 0.598 & -0.412 & -0.314 & -0.417 & -0.653 & -0.525 & 0.623 & 0.413 & 0.588 & -0.481 & 0.828 & 0.173 & -0.975 & $*$ \\
\hline
\end{tabular}

RWC: relative water content; $P H$ : plant height; $N L:$ number of leafs; SD: stem diameter; LA: leaf area; leaf area ratio; SLA: specific leaf area; LDM: leaf dry mass; SDM: stem dry mass; RDM: root dry mass; TDM: total dry mass; CARB: carbohydrates; PROT: protein; PROL: proline; S_MOIST: soil moisture; LBP: leaf biomass partitioning; SBP: stem biomass partitioning; RBP: root biomass partitioning; $S / R$ : shoot-to-root ratio.

\section{DISCUSSION}

Drought negatively affects vital processes in plants reducing growth and inducing metabolic imbalance $[6,34,35]$. However, the ability of plants to tolerate periods of drought depends, among other factors, on their stage of development at the time drought occurs. In the present study, $T$. gardneriana seedlings were approximately one month old when subjected to the withholding of water cycles, which occurred 15 days after the transference the seedlings to pots. This initial phase of plant development is the most critical [7]. Consequently, the drying of the surface layer of the soil is not only a stress factor, but can compromise the survival of the seedling.

The lowest values in growth observed in $T$. gardneirana seedlings as a consequence of the drought cycles demonstrate the direct effect of soil water content on the leaves relative water content (RWC) and consequently in the processes of cell division and expansion [36]. As these processes depend, at least in part, on turgor pressure [5], reduction in the degree of hydration found in the leaf tissue affected the growth. As the T. gardneriana seedlings were not able to maintain tissue hydration, the correlation matrix demonstrated that the reduction in growth parameters was more dependent on RWC than soil moisture. Thus, if the species had a good mechanism to maintain the tissue hydrated in drought conditions, as observerd to S7 plants (moderate stress), growth would probably not be as negatively affected, as observed to S14 plants, (under severe stress).

The negative effects of drought on plants inhabiting Caatinga areas during the initial growth relative to reductions in height, number of leaves, stem diameter and biomass production [10, 11, $25,37,38$ ] could demonstrate that, to some extent, such changes may help the species survive in semi-arid areas. Lower growth pattern in length, fewer and smaller leaves enables adapted plants to survive under conditions of limited water availability through better water management [10].

The reduced ability to maintain a favorable tissue hydrated (RWC) affected the growth to $T$. gardneriana seedlings. The lower accumulation of dry matter in various organs of $T$. gardneriana indicates lower net carbon assimilation, as reported for other species such as $H$. courbaril [39] 
and E. velutina [10] after severe water stress. This is demonstrated also by the direct relationship found to T. gardneriana between RWC X RDM (67\%), RWC X STM (66\%), RWC X LDM (53\%) and consequently RWC X TDM (66\%).

Changes in the growth pattern during the seedling phase in tropical dry forest species can ensure greater seedling survival and establishment in the natural environment. Change in the pattern of biomass partitioning, producing deeper roots in detriment to the shoot, is a widely studied mechanism [11, 34, 39, 40], reported as advantageous to plant survival $[4,9]$ as a characteristic of xeromorphism [41]. However, this inversion in the growth pattern was not observed in the $T$. gardneriana seedlings. Indeed, the species increased the dry biomass partitioning to the leaves and decreased to the root dry biomass.

This behavior could be related to the greater occurrence of this plant in riparian areas [18] or shallow areas near bodies of water. Since the species has broad geographical distribution, natural morphological characteristics of $T$. gardneriana do not seem to be altered by the imposition of a severe water stress. Indeed, this response highlight the great sensitivity of roots to water deficit. A drastic reduction in soil moisture can induce morphological and physiological changes to some species conferring hardness to the plants, but it does not occur with $T$. gardneriana. Thus, the initial hypothesis of the inversion of the growth pattern as a drought tolerance mechanism used by this species was refuted, since this xeric characteristic was not achieved in T. gardneriana seedlngs.

A reduction in leaf area and the shedding of leaves as a consequence of the prolonged period of soil water deficit and the increase in leaf area ratio (LAR) demonstrates the need for a greater area to produce the same amount of dry mass under stress situation [24]. It can be confirmed by the negative relationship between SOIL MOISTURE X LAR (38\%) and RWC X LAR (58\%), indicating that when the soil moisture decreases, a greater area is required for carbon sequestration. The leaf area ratio (LAR) and specific leaf area (SLA) are important to infer the degree of plasticity of the species since these variables represent the exportation or the retention of photoassimilates in the various organs [24]. If the LAR is reduced in response to water deficit, this may represent a greater efficiency in the useful area for the dry matter production. However, an increase in LAR values was observed in T. gardneriana when subjected to severe stress. Thus, the low PPI indices found for LAR and SLA demonstrate less morphological plasticity of $T$. gardneriana for living in xeric environments, represented herein by longer periods of intermittent drought (14 days between watering cycles).

In certain plants, water deficit limits cellular expansion and also slows the budding of leaves and branches, thereby reducing the total leaf area, which represents a water-savings for the plant $[10,39,42]$. Thus, the shedding of leaves also represents a water-savings since the surface area is reduced, besides minimizing the energy expended on maintenance. This is both a consequence of drought and a survival strategy.

On the other hand, the moderate stress represented by seven-day interval between irrigations (S7) did not appear to exert a negative effect on the growth variables of the seedlings, which shows that $T$. gardneriana has an intermediate degree of drought tolerance. This characteristic may account for the wide distribution of this plant in heterogeneous environments.

During osmotic regulation plants need to reduce the cellular water potential to maintain water inflow [43]. Stressed seedlings (S14) also showed higher values of compatible solutes, which are osmotically active. However, the drastic reduction in RWC (54\%) in the S14 plants indicates that the leaves were in process of dehydration, which contradicts the concept of osmotic adjustment by a marked reduction in cellular volume. Thus, the increase of carbohydrates and proline observed in the leaves of S14 of T. gardneriana seedlings indicate an important role in osmoprotection rather than to osmoregulation to $T$. gardneriana seedlings.

In addition to RWC, the protoplasmic analysis revealed that the leaves of the S14 seedlings exhibited $36 \%$ of membrane damage in comparison to the control treatment. Proline had an inverse relationship (91\%) to RWC and was the most expressive solute in response to water stress in T. garneriana, along with being the physiological parameter of greatest plasticity. These results demonstrate that the accumulation of solutes in T. gardneriana leaves under more severe cycles of drought (S14) plays an important role as an osmoprotectant, especially proline, which actively participates in the membrane maintenance and protein stabilization, acting as a molecular 
chaperone, reactive oxygen species scavenger, regulator of redox homeostasis as well as a source of carbon and nitrogen [6, 13, 25, 44, 45]. Among all organic solutes evaluated in the present study, the high amount of proline confers a better performance to overcome the negative effects of drought in $T$. gardneriana seedlings.

Plant survival is strongly dependent on environmental factors and water availability is the most determinant because it affects both short-term responses and the evolution of phenotypic plasticity [46]. Species in savanna environments modify their morphology less and develop physiological plasticity more, in response to low water availability combined with high irradiance [47]. Thus, the results found to T. gardneriana could be achieve as exhibiting physiological rather than morphological plasticity [46]. If a morphological response does not occur, it does not necessarily mean that a plant lacks plasticity, because a relative morphological stability trait could be mediated by substantial physiological characters [48]. Although the synthesis and accumulation of osmorregulators itself do not prove plasticity because it does constitute reversible and highly dynamic processes, that result from rapid acclimation to the environmental conditions, this behavior acting together with other physiological mechanisms may be responsible for $T$. gardneriana survival in a heterogeneous environment. This way, physiological plasticity plays an important role in the acclimatization of plants [48, 49].

Triplaris gardneriana, could be characterized as moderate drought-tolerant species when facing intermittent drought situation in the early stages of development. It could be demonstrated by the continuity in growth rhythms of height, lateral stem expansion, and the budding of new leaves, as well as the production of dry biomass, the maintenance of tissue hydration and membrane integrity among the plants subjected to seven-day suspension cycles (S7) between irrigations. The S7 plants exhibited shared characteristics with the control plants, but had divergence in the variables RWC, PH, SLA, SBP and RBP (Figure 6), which determined the differentiation of these plants and indicated morphological variations at intermediate levels of water stress.

\section{CONCLUSION}

Triplaris gardneriana seedlings do not exhibit efficient mechanisms for tissue hydration maintenance when subjected to severe drought, which strongly compromises initial growth. Nevertheless, it does accumulate proline contributing to minimizing the damage caused to the protoplasm during desiccation. These results suggest $T$. gardneriana displays physiological rather than morphological mechanisms conferring a moderate degree of drought tolerance to seedlings which lends support to the assertion that physiological plasticity plays an important role in the acclimatization of plants. The plastic changes observed in the seedlings are more physiological than morphological, but do not confer adequate conditions for establishment in environments with a marked reduction in soil water availability or severe water stress.

\section{ACKNOWLEDGMENT}

The authors thank Márcia A. Rocca for the critical reading and correction of this version in English, the Coordination for the Improvement of Higher Education (CAPES) and the Foundation for Research Support of the State of Sergipe (FAPITEC) for the financial support (2417/2013 CAPES/FAPITEC/SE), the Center for Ecology and Environmental Monitoring NEMA/UNIVASF, the Integration Project of the São Francisco River with the North-Northeast Hydrographic Basins - PISF and the Ministry of Regional Development - MDR for the seeds used in this research and to São Paulo State Research Support Foundation (FAPESP) for doctoral scholarships (Process nº 2018 / 24514-7) granted to JRV Aragão.

\section{REFERENCES}

1. Ricklefs RE. A Economia da Natureza. 6th ed. Rio de Janeiro: Ed. Koogan; 2010. 
2. Paradizo IC, Macieira BPB, Gama VN, Zanetti LV, Cuzzuol GRF. A plasticidade fenotípica como indicador de arbóreas não pioneiras mais tolerantes à elevada irradiância. Pesquisa Florestal Brasileira. 2015;35(84):359-69. doi: 10.4336/2015.pfb.35.84.927

3. Santos JC, Leal IR, Almeida-Cortez JS, Fernandes GW, Tabarelli M. Caatinga: the scientific negligence experienced by a dry tropical forest. Trop Cons Sci. 2011;4(3):276-86. doi: $10.1177 / 194008291100400306$

4. Ferreira WN, de Lacerda CF, da Costa RC, Medeiros Filho S. Effect of water stress on seedling growth in two species with different abundances: the importance of Stress Resistance Syndrome in seasonally dry tropical forest. Acta Botanica Brasilica. 2015;29(3):375-82. doi: 10.1590/0102-33062014abb0045

5. Jaleel CA, Manivannan P, Wahid A, Farooq M, Al-Juburi HJ, Somasundaram R, et al. Drought stress in plants: a review on morphological characteristics and pigments composition. Int $\mathrm{J}$ Agric Biol. 2009;11(1):100-5.

6. Silva EC, Albuquerque MB, de Azevedo Neto AD, da Silva Junior CD. Drought and Its Consequences to Plants - From Individual to Ecosystem. In: Akinci S, editor. Responses of organisms to water stress. Londres (UK): InTech; 2013. p. 17-47. doi: 10.5772/53833

7. Savi T, Love VL, Dal Borgo A, Martellos S, Nardini A. Morpho-anatomical and physiological traits in saplings of drought-tolerant Mediterranean woody species. Trees. 2017;31(4):1137-48. doi: 10.1007/s00468-017-1533-7

8. Nardini A, Casolo V, Dal Borgo A, Savi T, Stenni B, Bertoncin P, et al. Rooting depth, water relations and non-structural carbohydrate dynamics in three woody angiosperms differentially affected by an extreme summer drought: Rooting depth and plant hydraulics. Plant, Cell \& Environm. 2016;39(3):61827. doi: $10.1111 /$ pce. 12646

9. Ryan MG. Tree responses to drought. Tree Physiol. 2011;31(3):237-39. doi: 10.1093/treephys/tpr022

10. da Silva EC, Silva MF, Nogueira RJ, Albuquerque MB. Growth evaluation and water relations of Erythrina velutina seedlings in response to drought stress. Braz J Plant Physiol. 2010;22(4):225-33. doi: 10.1590/S1677-04202010000400002

11. Silva EC, Prado TB, de Alcântara RN, da Silva Junior CD, Nogueira LC. Different levels of water deficit induces changes in growth pattern but not in chlorophyll fluorescence and water relations of Hancornia speciosa Gomes seedlings. Sci Plena. 2016;12(2):021001. doi: 10.14808/sci.plena.2016.021001

12. Medeiros DB, da Silva EC, Santos HRB, Pacheco CM, Musser RS, Nogueira RJMC. Physiological and biochemical responses to drought stress in Barbados cherry. Braz J Plant Physiol. 2012;24(3):181-92.

13. Valliyodan B, Nguyen HT. Understanding regulatory networks and engineering for enhanced drought tolerance in plants. Current Opinion Plant Biol. 2006;9(2):189-95. doi: 10.1016/j.pbi.2006.01.019

14. Krasensky J, Jonak C. Drought, salt, and temperature stress-induced metabolic rearrangements and regulatory networks. J Experim. Bot. 2012;63(4):1593-608. doi: 10.1093/jxb/err460

15. Hare PD, Cress WA. Metabolic implications of stress-induced proline accumulation in plants. Plant Growth Reg. 1997;21:79-102. doi.org/10.1023/A:1005703923347

16. Turner NC. Turgor maintenance by osmotic adjustment: 40 years of progress. J Experim Bot. 2018;69(13):3223-33. doi: 10.1093/jxb/ery181

17. Azevedo Neto AD, Nogueira RJMC, Melo Filho PA, Santos RC. Physiological and biochemical responses of peanut genotypes to water deficit. J Plant Interactions. 2010;5(1):1-10. doi: $10.1080 / 17429140902999243$

18. de Lacerda AV, Barbosa FM, Soares JJ, Barbosa MRV. Flora arbustiva-arbórea de três áreas ribeirinhas no semiárido paraibano, Brasil. Biota Neotropica 2010;10(4):275-84. doi: 10.1590/S167606032010000400032

19. Fagundes NCA, Braga LL, Silva WA, Coutinho CA, Neves WV, de Souza RA, et al. Survival of saplings in recovery of riparian vegetation of Pandeiros river (MG). Floresta Amb. 2018;25(2):1-11. doi: 10.1590/2179-8087.021215

20. Lemos JR, Zappi DC. Distribuição geográfica mundial de plantas lenhosas da Estação Ecológica de Aiuaba, Ceará, Brasil. Rev Bras Biociências. 2012;10(4):446-56.

21. Pontara V, Bueno ML, Scremin-Dias E. Flooding avoidance Triplaris gardneriana Wedd. (Polygonaceae): growth and morpho-anatomical aspects. Acta Sci Biol Sci. 2016;38(3):341-46. doi: 10.4025/actascibiolsci.v38i3.31267

22. Tabosa FRS, Almeida ÉM, Melo E, Loiola MIB. Flora do Ceará, Brasil: Polygonaceae. Rodriguésia. 2016;67(4):981-96. doi: 10.1590/2175-7860201667409

23. Bonfim-Silva EM, Kroth BE, Rezende D. Desenvolvimento inicial de gramíneas submetidas ao estresse hídrico. Rev Caatinga. 2011;24(2):180-86.

24. Benincasa MMP. Análise de crescimento de plantas: noções básicas. Jaboticabal: FUNEP; 2003. 
25. Freitas RS, da Silva EC. Respostas fisiológicas de mudas de Aspidosperma pyrifollium (Apocynaceae) à ciclos de suspensão de rega. Sci Plena. 2018;14(5):051201. doi: 10.14808/sci.plena.2018.051201

26. Weatherley PE. Studies in the water relations of the cotton plant. New Phytol. 1950;49(1):81-97. doi: 10.1111/j.1469-8137.1950.tb05146.x

27. Vasquez-Tello A, Zuily-Fodil Y, Thi ATP, da Silva JBV. Electrolyte and pi leakages and soluble sugar content as physiological tests for screening resistance to water stress in Phaseolus and Vigna species. J Experim. Bot. 1990;41(7):827-32. doi: 10.1093/jxb/41.7.827

28. Bates LS. Rapid determination of free proline for water-stress studies. Plant and Soil. 1973;39:205-07.

29. Bradford MM. A rapid and sensitive method for the quantitation of microgram quantities of protein utilizing the principle of protein-dye binding. Analytical Biochem. 1976;72(2):248-54.

30. Dubois M, Gilles KA, Hamilton JK, Rebers PA, Smith F. Colorimetric method for determination of sugars and related substances. Analytical Chem. 1956;28:350-56.

31. Valladares F, Wright SJ, Lasso E, Kitajima K, Pearcy RW. Plastic phenotypic response to light of 16 congeneric shrubs from a Panamanian rainforest. Ecology. 2000;81(7):1925-36. doi: 10.1890/00129658(2000)081[1925:PPRTLO]2.0.CO;2

32. Valladares F, Gianoli E, Gómez JM. Ecological limits to plant phenotypic plasticity. New Phytologist. 2007;176:749-63. doi: 10.1111/j.1469-8137.2007.02275.x

33. Rao CR, Mitra SK. Generalized inverse of a matrix and its applications. Proceedings of the Sixth Berkeley Symposium on Mathematical Statistics and Probability. Volume 1: Theory of statistics. California (US): The Regents of the University of California; 1972.

34. Osakabe Y, Osakabe K, Shinozaki K, Tran L-SP. Response of plants to water stress. Frontiers Plant Sci. 2014;5:1-8. doi: 10.3389/fpls.2014.00086

35. Rawat JM, Rawat B, Tewari A, Joshi SC, Nandi SK, Palni LMS, et al. Alterations in growth, photosynthetic activity and tissue-water relations of tea clones in response to different soil moisture content. Trees. 2017;31(3):941-52. doi: 10.1007/s00468-016-1519-x

36. Basu S, Ramegowda V, Kumar A, Pereira A. Plant adaptation to drought stress. F1000Research. 2016;5:1-10. doi: 10.12688/f1000research.7678.1

37. dos Santos Junior JL, Oliveira MFC, da Silva EC. Acúmulo de solutos orgânicos em mudas de Ceiba glaziovii (Kutze) Kum. em resposta à seca intermitente. Sci Plena. 2020;16(1):011201. doi: 10.14808/sci.plena.2020.011201

38. Lucio DM, Dantas SG, dos Santos JRM, Praxedes SC. Differences in water deficit adaptation during early growth of Brazilian dry forest Caatinga trees. J Agri For. 2017;63(1):59-68. doi: 10.17707/AgricultForest.63.2.05

39. do Nascimento HHC, Nogueira RJMC, da Silva EC, da Silva MA. Análise do crescimento de mudas de jatobá (Hymenaea courbaril L.) em diferentes níveis de água no solo. Rev Árvore. 2011;35:617-26.

40. Silva EC, Nogueira RJ, Vale FH, de Melo NF, de Araújo FP. Water relations and organic solutes production in four umbu tree (Spondias tuberosa) genotypes under intermittent drought. Braz J Plant Physiol. 2009;21(1):43-53. doi: 10.1590/S1677-04202009000100006

41. Lisar SYS, Motafakkerazad R, Mosharraf M, Rahm IMM. Water stress in plants: causes, effects and responses. In: Rahman IMM, editor. Water Stress. Londres (UK): InTech; 2012. p. 1-14. doi: $10.5772 / 39363$

42. Silva-Pinheiro J, Lins L, Souza FC, da Silva CEM, Moura FBP, Endres L, et al. Drought-stress tolerance in three semi-arid species used to recover logged areas. Braz J Bot. 2016;39(4):1031-8. doi: 10.1007/s40415-016-0309-4

43. Silva EC, Nogueira RJMC, de Azevedo Neto JAD, Brito JZ, Cabral EL. Aspectos ecofisiológicos de dez espécies em uma área de caatinga no município de Cabaceiras, Paraíba, Brasil. Iheringia Série Botânica. 2004;59(2):201-05.

44. Pospisilova J, Haisel D, Vankova R. Responses of transgenic tobacco plants with increased proline content to drought and/or heat stress. Am J Plant Sci. 2011;2(3):318-24. doi: 10.4236/ajps.2011.23036

45. Mwenye OJ, van Rensburg L, van Biljon A, van der Merwe R. The role of proline and root traits on selection for drought-stress tolerance in soybeans: a review. S Afri J Plant Soil. 2016;33(4):245-56. doi: $10.1080 / 02571862.2016 .1148786$

46. Gimeno TE, Pias B, Lemos-Filho JP, Valladares F. Plasticity and stress tolerance override local adaptation in the responses of Mediterranean holm oak seedlings to drought and cold. Tree Physiol. 2008;29(1):87-98. doi: 10.1093/treephys/tpn007

47. Goulart MF, Lovato MB, Barros FV, Valladares F, Lemos-Filho JP. Which extent is plasticity to light involved in the ecotypic differentiation of a tree species from savanna and forest?: Ecotypic differentiation in savanna and forest. Biotropica. 2011;43(6):695-703. doi: 10.1111/j.17447429.2011.00760.x 
48. Gratani L. Plant phenotypic plasticity in response to environmental factors. Advances in Botany. 2014;2014:1-17. doi: 10.1155/2014/208747

49. Zunzunegui M, Ain-Lhout F, Barradas MCD, Álvarez-Cansino L, Esquivias MP, Novo FG. Physiological, morphological and allocation plasticity of a semi-deciduous shrub. Acta Oecologica. 2009;35(3):370-9. doi: 10.1016/j.actao.2009.02.004 